\title{
Lessons from a giant: homage to Gabriel Richet
}

\author{
Giorgina B. Piccoli
}

Published online: 10 December 2014

(C) Italian Society of Nephrology 2014

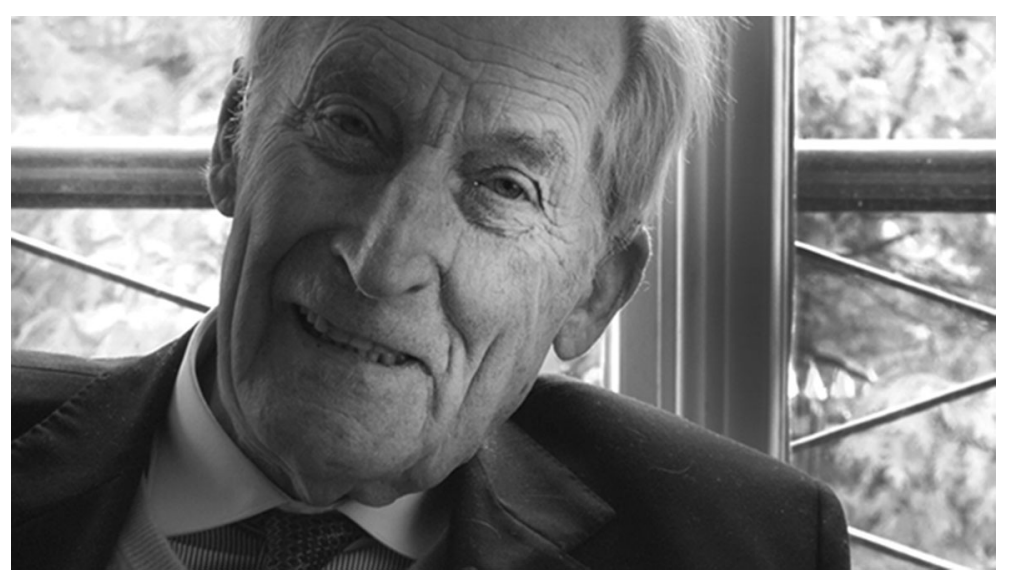

A few days ago, on an October afternoon, Gabriel Richet, remembered by his followers as a giant of nephrology, passed away. He was almost 98 years old. When a giant or a hero-as Gabriel Richet's life reveals him to be-passes away, it is a time of sorrow and an unavoidable sense of loss, but it is also a time for memory, and memory can bring joy. This is why I would now like to share some of his most recent interviews, recorded as part of an ongoing project on the pioneers of French and European nephrology was started.

Gabriel Richet left us far more than an impressive list of achievements, attentively gathered by his former collaborators and readily available, with the rapidity the Internet allows, on the most important official sites of the ERAEDTA, the ISN and the French Society of Nephrology. He

\section{G. B. Piccoli ( $\square)$}

Giorgina Barbara Piccoli, SS Nephrology, ASOU san Luigi

Gonzaga, Department of Clinical and Biological Sciences,

University of Torino, Turin, Italy

e-mail: gbpiccoli@yahoo.it left us a message of hope and beauty, with his critical, ironic and benevolent approach to humankind and the need for an attitude of perennial discovery.

When Gabriel Richet introduced himself, he started with the war. Born during the First World War, he fought during the Second for the freedom of his country. "I am a man who always had a lot of luck. I did a lot of silly things and generally the result was quite joyful. That's about it. I was very bold during the war (...)". He doesn't speak of the victories he took part in, but of his wounds: the hero is one who overcomes an injury, not an invincible person who doesn't feel or understand pain: "I was injured, a bullet entered the top of my right thigh and was found against the left femoral artery; $60 \mathrm{~cm}$ of stitches and then 60 days later, I returned to the front. That is to say that I am a rather adventurous character."

Over more than $3 \mathrm{~h}$ of interviews, he never spoke of his prizes, the honours received, or his practical achievements. He talked about his youth; about the enchantment of discovery; of the need to remain humble, capable of feeling surprise, enchantment; of the ability to change one's point 
of view: "First, it's necessary to be specialized and second, it's necessary to have a very open mind. How do you keep an open mind? Well, it's very simple: by examining your patients". Without any fear of being simplistic, he proudly defended "the right to astonish oneself, the need to astonish oneself, to find an anomaly in the reasoning process, to think outside of the box...".

He was a keen observer of humankind: the description of the story of Marius Renard is a masterpiece of attention to detail: details of time and date, the work the patient was doing, the flowers at his funeral. "On December 18, 1952, the apprentice roofer Marius Renard, who lived in a small village $60 \mathrm{~km}$ north of Paris, near Beauvais, fell from a roof and his right kidney exploded (...). What the surgeon did not know was that this poor boy had only one functioning kidney. His mother proposed to donate one of her kidneys because she had seen a film featuring a kidney transplant. The mother had almost all known groups and all subgroups identical to those of her son, and a kidney transplant was carried out on December 25 at $9 \mathrm{pm}$ at the Necker Hospital (...). The urea clearance dropped dramatically to $18 \mathrm{ml} 20$ days after transplantation (...), and Marius died. At his funeral, in his village, $50 \mathrm{~m}$ of street were blocked by flowers sent from all round the world. International public opinion was telling medicine: "Find a solution for kidney transplants". And, as always, it is by reflecting on well-observed single cases that medicine progresses."

It was because of his adventurous character, his strength and his deeply nonconventional approach that, after about 10 years spent with Jean Hamburger, the "inventor" of the name "Nephrology", Gabriel Richet left the prestigious Necker Hospital for a new adventure in Tenon, at that time a small peripheral hospital. "We had nothing. I found myself in the same situation as Hamburger at Necker in 1951 when he arrived, but I had learned from all the successes and failures we had been through...". What was important was friendship, cooperation and a school that would outlive his own time: "When I think that, against all logic, Ardaillou and Amiel followed me to work at Tenon, where there was no hope of concrete and creative work...
25 years ago I left Tenon to retire, and I think Tenon's school still lives on after my departure."

He was a man of freedom, and a free thinker. He chose unusual pathways, described them in unusual ways, and his never-ending lesson may come of age at a time in which the economic crisis seems to affect all that appeared established: "It's necessary to have an educated mind, but education should not demolish thinking, as Roger Martin du Gard wrote in "The Thibaults": Let's hurry not to be certain... If you let yourselves be seduced by the old man who I am, do read "The Thibaults" with its 2000 pages...."

But the last, vital lesson is about love: love of medicine, love of patients, love of life: "I would say to a student: Choose a branch that you love; to love it, you must know it and, therefore, have measured its past and its possible future (...)".

The end of his first interview is probably the best way to depict this tall, blue-eyed, charming and handsome old gentleman, whose heritage should make us reflect on the values and the beauty of our profession: "A doctor is a man who decides; when he writes out a prescription, he orders.... But is it possible to give an order and decide without heart? Unfortunately, many do not share my opinion, but that's life.... I am like the Queen of Holland", whose motto is: "I will maintain".

With these words, he proudly smiled, rose and offered us a glass of white wine.

\section{Further reading and listening}

http://www.theisn.org/news/latest-isn-news/leadership/gab riel-richet-1916-2014/itemid-455

http://www.era-edta.org/page-3-14-136-136-gabrielrichet. html

http://societedenephrologie.zenfolio.com/pionieri http://www.soc-nephrologie.org/enephro/histoire/inmemor iam/richet.htm e

Acknowledgments Thanks to Brigitte Lang for the translation of the EDTA interview and to Gilberto Richiero for the photograph of Gabriel Richet.

Conflict of interest None. 